\title{
The Philosophical Dilemma of the Implementation of Justice Theory: Problems in Utilizing Land Rights between the Amungme Indigenous Tribe and PT Freeport Indonesia
}

\author{
Muhammad Bintang Pratama ${ }^{1}$, Muhammad Adib Afiq ${ }^{2}$, Novita Ratna Cindi $F^{3}$. Savira Auril ${ }^{4}$ \\ Faculty of Law, Universitas Sebelas Maret. E-mail: bintangmuh8@gmail.com
}

\begin{abstract}
This study analyzes the philosophical dilemma of the implementation of the theory of justice, the problem of the use of land rights between the Amungme Indigenous Tribe and PT Freeport Indonesia. This research is normative legal research using secondary data sources through prescriptive literature studies. The results show that there are problems in the use of land ownership rights; there are contradictions in the use of reasons for claiming ownership rights over the disputed land. The Amungme Adat tribe adheres to the theory of natural law with concrete implementation in the form of traditional customs which considers disputed land as ancestral heritage land, which is the absolute right of the Amungme Adat tribe. Meanwhile, PT Freeport Indonesia uses positivist legal theory with concrete implementation in the form of the use of Contract of Work and Agreement as positive law which is used as a strong basis for claiming ownership rights over the disputed land. In this research, we will discuss the philosophical dilemma of the implementation of the theory of justice comprehensively, the problem of the use of land rights between the Amungme Indigenous Tribe and PT Freeport Indonesia based on the use of the theory of justice. The limitation of this research lies in the study using literature data sources without empirical research. In the future, it is hoped that similar research can use this research as an essential reference in conducting research that can obtain factual data in the field so that it can provide more accurate results.
\end{abstract}

Keywords: Philosophical Dilemma, Theory of Justice, Land Ownership, Amungme Indigenous Tribe, PT Freeport Indonesia.

\section{Introduction}

Earth, water and space, as well as the natural wealth contained therein, are a reflection of the history of mankind in fulfilling their survival. The surface of the earth, in general, consists of land, which is one of the resources that can be used as the basis for national development (Supriyadi, 2010). Land inherent in the national territory of Indonesia is essentially a unified homeland that can be utilized by various types of parties, both public and private entities (Mira Novana Ardani, 2017).

The nature of the land which has an important role in influencing the lives of many people encourages the role of the state in controlling the land as stated in Article 33 paragraph (3) of the 1945 Constitution of the Republic of Indonesia Article 33, "Earth, water, and the space contained therein, in the highest level is controlled by the State. " The Basic Agrarian Law (UUPA) of 1960 which was implemented on September 24, 1960, became the first milestone in the positive law governing land in Indonesia to date.

The regulation of control over land rights in the UUPA is a technical description of the mandate of the 1945 Constitution of the Republic of Indonesia. Article 33 paragraph (3) 
of the 1945 Constitution of the Republic of Indonesia, in general, regulates land tenure which is intended to improve the welfare of society in general without discriminating based on certain criteria, including financial strength, power of influence of position, the strength of relations with stakeholders. (Levina Azaria Winantyo, 2018).

The principle that underlies the birth of land ownership rights in the UUPA begins with the use of land which must be adjusted to the nature of its rights so that it can provide benefits for the welfare and happiness of the community and the State. Existing interests should be balanced according to the functions and benefits to be received by each party trying to manage them (Kartini Mulyadi \& Gunawa Widjaja, 2007). The nature of the land which is not only a medium in fulfilling economic resources but also has a sacred role that must be maintained by indigenous peoples (Mira Novana Ardani, 2017).

Control over land as an effort to have maximum land ownership to generate profits for those who actively manage the land. Land as a pillar of development in supporting various activities that can increase the productivity of those who use the land. (Nyoman Serikat Putra Jaya, 2016). The social justice that the state intends to achieve as a concrete implementation of the 1945 Constitution of the Republic of Indonesia is reflected in the recognition of the existence of indigenous peoples within it (Laurentius Arliman, 2015). The legal protection of every citizen of the Republic of Indonesia is implicitly and explicitly regulated in the 1945 Constitution of the Republic of Indonesia (hereinafter referred to as the 1945 Constitution of the Republic of Indonesia).

The Amungme tribe as part of the indigenous community unit has ancestral origins that are hereditary in exploring certain geographies, have a unique value system, ideology, and unique order of community life (M. Syamsudin, 2008). Protection of customary law communities is generally regulated in Article 18B paragraph (2) of the 1945 Constitution of the Republic of Indonesia, which reads: "The state recognizes and respects the unity of indigenous peoples and their traditional rights as long as they are still alive and under the development of society and the principles of the Unitary State of the Republic of Indonesia. which is regulated in law".

The Amungme Adat tribe which is included as a customary community unit is recognized and protected based on the 1945 Constitution of the Republic of Indonesia, especially in the UUPA specifically regulated in Article 20 which outlines that property rights are hereditary, strongest, and full rights that can be owned by people over land. keeping in mind the stipulation that all land has a social function.

The problem of land ownership disputes between the Amungme Indigenous Tribe and PT Freeport Indonesia is essentially motivated by the use of different legal claims for proof of land ownership among the parties. The Amungme Customary Tribe through representatives of the Amungme Community Development Institute (hereinafter referred to as LPMA) and the Amungme Tribe Customary Institution (hereinafter referred to as LASA) filed a claim for ownership of disputed land on the basis that the disputed land is customary ulayat land, so the land should belong to the Amungme Indigenous Tribe.

This was reinforced by the statement of the LPMA and LASA when they held a closed meeting with the Ministry of Energy, Resources and Minerals of the Republic of Indonesia 
discussing the problems of controlling disputed land which is claimed to be the communal land of the Amungme Adat Tribe. Disputed land claimed by the Amungme Indigenous Tribe as the party with the right to manage the land. Because the use of land carried out by PT Freeport Indonesia is considered only to cause losses, using concrete evidence in the form of environmental destruction around the mining area (Addi M. Idham, 2017).

The disputed land that is being fought over by the Amungme Adat Tribe is classified as a no-man's land because there is no concrete deed and a notary showing ownership of the land. So that according to the representatives of the Amungme Indigenous Tribe, the land is customary communal land, especially PT Freeport, only has the right to use the concession given by the Government. Land tenure by Freeport without a Free Prior Inform Consent (FPIC) process, that is, without involving the community in exercising the right to determine all types of activities carried out in communal land areas, which are disputed lands (Indra Nugraha, 2017).

Meanwhile, from the perspective of PT Freeport Indonesia, disputed land is legally owned land based on a concession granted by the Indonesian Government in 1967. PT Freeport Indonesia carries out Mining Business Permits (IUP) activities under the provisions of laws and regulations that have been in force since 1967 which line Besar provides facilitation for private investment activities in the mining sector operating within Indonesia.

We are starting with the issuance of Law Number 1 of 1967 concerning Foreign Investment (PMA Law 1/1967), Law Number 6 of 1967 concerning Domestic Investment (PMDN Law 6/1967), Law Number 11 of 1967 concerning Principal Mining (Mining Law 11/1967) as amended by Law Number 4 of 2009 concerning Mineral and Coal Mining (Minerba Law 4/2009) (Dianto Bachriadi, 2017).

The fulfilment of the obligations that have been carried out by PT Freeport Indonesia is reflected in the payment of compensation for the customary rights of the Amungme Indigenous Tribe under the provisions of Article 25 and Article 27 of the Mining Law 11/1967 j.o. Minerba Law 4/2009. PT Freeport Indonesia has provided $1 \%$ of the total profit each year to the Amungme Indigenous People who are around the mining operation area, especially in the Mount Getsberg and Mount Etsberg areas (The Global Review, 2017).

The urgency of this writing is used to examine the problems in the use of land rights between the Amungme Indigenous Tribe and PT Freeport Indonesia in terms of legal theory teachings. The conflict over the use of land ownership rights lies based on the reasons used by each party to claim ownership rights. The disputed land, which is an exciting thing to study from a legal theory point of view. The assessment lies based on the reasons for the claims used by each party concerning the legal theory that is relevant to the problems of land disputes. In the future, it is hoped that this writing can be used as study material in resolving dispute disputes between the Amungme Indigenous Papuans and PT Freeport Indonesia.

Based on the background that has been described above, the writer wants to formulate the problem to be studied. The formulation of the problem in a study plays an essential role in determining the right problem solving and can achieve the desired goals (Peter Mahmud Marzuki, 2014). AThe problems that will be examined in this research are: 
1. How did the initial causes of the conflict over the use of land rights between the Amungme Papua tribe and PT Freeport Indonesia occur?

2. How can the theory of justice be used as an academic effort to mediate the resolution of the conflict over the use of land rights between the Amungme Indigenous Papuans and PT Freeport Indonesia?

The research method used is in the form of normative research through library research through the collection of legal materials (Peter Mahmud Marzuki, 2014). The author's legal research is prescriptive, where the process of finding legal rules, legal principles, legal doctrine results in arguments and theories related to the application of time deposits. Peter Mahmud Marzuki argues that legal research is not about data (Peter Mahmud Marzuki, 2014).

Solving legal issues to provide a prescription of what research sources should be required or what is referred to as legal material. Research sources can be divided into research sources in the form of primary legal materials, secondary legal materials, and non-legal materials. Where the whole research method focuses on examining the use of the theory of justice as a part of legal philosophy towards concrete implementation to mediate the resolution of the conflict over the use of land rights between the Amungme Indigenous Tribes of Papua and PT Freeport Indonesia.

\section{The Initial Cause of the Conflict in the Use of Land Ownership Rights between the Amungme Indigenous People of Papua and PT Freeport Indonesia.}

The Freeport Indonesia mine is one of the largest gold mines in the world. Not only gold, but the Grasberg mountain mine also contains other ores, namely copper and silver. The discovery of treasure troves in Papua began with the adventures of Dutch explorer Jean Jacques Dozy in 1936. Dozy climbed Mount Papua to find new oil exploration fields when he joined the oil company, Nederlandsch Nieuw Guinee Petroleum Maatschappij (NNGPM). Reports of the discovery of this mine were later abandoned in the Dutch library during World War II and were reported to be dusty. At that time, world conditions were not supportive, ahead of the outbreak of World War II which involved many countries, including the Netherlands. (Anggun P. Situmorang, 2018).

In April 1960, Forbes Wilson, a geologist working for Freeport, came to Timika and made an expedition to Grasberg. The expedition was carried out after reading the report of Jean Jacques Dozy, who first visited Grasberg with two of his colleagues. Wilson was not alone. He was accompanied by an Amungme tribal leader, Moses Kilangin - a church planter in Timika. Forbes Wilson and Moses Kilangin travelled towards the Mawati River, crossing the Tsinga River. From the Tsinga Valley, they headed west of the Waa Valley. Then they followed the route of the Dozy expedition team. At that time, Moses Kilangin did not know that his journey with Forbes Wilson and what they found would destroy his tribe, his ancestral land (Wan Ulfa Nur Zuhra, 2017).

Sometime later, Wilson reported the findings to Freeport President Bob Hills in New York, United States. He said that from an area of 14 hectares, only one hectare was without copper ore. Meanwhile, the depth has only reached a hundred meters. These tantalizing 
findings made the Freeport leadership very happy with the possibility of abundant benefits to be obtained. In Lisa Pease's report, a journalist for Probe Magazine America, Freeport has received the First Contract of Work on April 50, 1967. This business agreement is valid for 30 years and can be extended. Lisa Pease also found that Freeport was doing various ways to obtain permits and to extend its work contract. (Anggun P. Situmorang, 2018).

From the perspective of the Amungme Tribe, since the beginning PT Freeport Indonesia operated, they have never been involved in the making of a work contract. They are the customary land owners. In Article 135 of Law Number 4 of 2009 concerning Mineral and Coal Mining, it is stated that IUPK holders can only carry out their activities after obtaining approval from the holders of land rights.

Chairman of the Amungme Indigenous Community in the Timika area, Papua, Odizeus Benal said that he had lost his rights to voice ideas. They are also not involved in making decisions regarding the use of natural resources in their territory, including the issue of PT Freeport Indonesia. Odizeus said that the neglect of indigenous peoples' rights had occurred since PT Freeport McMoran and the Indonesian government signed the (first) Contract of Work I (first) in 1967 (Tiara Sutari, 2017).

Meanwhile, according to the perspective of PT Freeport Indonesia, this company started operating in Mimika Regency, Papua Province from 1967 until now based on two contracts of work. Contract of Work I in 1967 with a contract period of 30 years. Then in 1991, a Work Contract II was made with a mass valid for 50 years starting from the Contract of Work I. Based on this Contract of Work II. PT Freeport's mining area increased by 6.5 million acres (or PT Freeport Indonesia began operating in the Mimika district, Papua province in 1967 until now based on two contracts of work.

In addition to the work contract obtained from the government, PT Freeport has also obtained a permit from the Amungme tribe, which is a tribe whose land becomes Freeport's mining land by holding the January Agreement on January 8, 1974. January Agreement is an agreement containing a cooperation agreement between the Amungme and Freeport tribes (Adrianus Bintang Hanto Nugroho, 2014). One of the substances of the January Agreement is that PT Freeport provides social facilities in the form of schools, health clinics, housing and shopping centres. Apart from these facilities, it was also agreed that Freeport should provide employment opportunities for Amungme people under the company's development.

Based on the II work contract, PT Freeport's mining area has increased by 6.5 million acres (or an area of 2.6 million ha), (called Block B). From Block B, exploration has been undertaken for around 500 thousand acres (around 203 thousand ha), types of mining in the form of gold, silver, copper, and other associated materials. The majority of shares held in PT Freeport Indonesia are owned by Freeport McMoRan Copper and Gold Inc, with a percentage of $94.6 \%$. In comparison, the remaining $96.3 \%$ is owned by the Indonesian government. So far Freeport McMoRan has explored two places in Tembagapura, Mimika Regency, Papua Province. These two places include the Erstberg mine (Operations started from 1967-1988), and the Grasberg mine (Operations started from 1988-present) (Adrianus Bintang Hanto Nugroho, 2014). 
Meanwhile, according to the author's opinion, the problematic conflict use of land ownership rights between the Amungme Indigenous Tribe and PT Freeport Indonesia can occur due to differences in the use of grounds in claims to ownership rights over the disputed land. Land disputes that occur between the Amungme Indigenous Tribe and PT Freeport Indonesia generally occur in the Mimika area that stretches along Mount Ersberg. PT Freeport Indonesia, which complaints to use Contracts of Work and Agreements as the primary basis for claims that have allowed them to invest in mining for more than 50 years on Indonesian soil, is a clear example of positivistic law. The flow of positivistic legal theory adhered to by PT Freeport Indonesia is reflected in the prioritization of written rules (Contracts of Work and Agreements) in strengthening ownership of property rights over the disputed land.

Whereas the Amungme Adat Tribe uses the argument in the UUPA and the Mineral and Coal Law which states that disputed land should belong to the Amungme Adat Tribe because basically, the land is ancestral land which is hereditary so it cannot be owned by anyone other than the tribe. Custom Amungme. Moreover, the operational activities carried out by PT Freeport Indonesia are suspected of damaging the environment and only prioritizing profits without considering environmental sustainability and the rights of the Amungme Indigenous Tribe to customary ulayat lands.

Therefore, the authors are interested in examining comprehensively how the basis of reasons used by each party is based on the teachings of the relevant legal theory as a knife of analysis in looking at how 'ideal' the basis for reasons used by each party in their efforts to win ownership claims over the disputed land.

\section{The Use of Justice Theory as Academic Efforts to Mediate the Settlement of Conflict in the Use of Land Rights between the Amungme Indigenous Papuans and PT Freeport Indonesia.}

One of the foreign corporations that first came to Indonesia was Freeport based in Louisiana, United States. PT Freeport Indonesia is the first foreign mining corporation operating in Indonesia after the enactment of Law No.1 of 1967 concerning Foreign Investment. The Contract of Work between the Indonesian Government and PT Freeport Indonesia was first signed on April 7, 1967. PT Freeport Indonesia adheres to the legal theory of legal positivism. The operational activities carried out by PT Freeport Indonesia rely on a Contract of Work and an Agreement as a strong basis for the use of rights to the disputed land (Al Araf, Anton Aliabbas, dkk., 2011).

The Indonesian Forum for the Environment (WALHI) has discovered fundamental problems arising from mining activities carried out by PT. Freeport Indonesia, namely: (1) about the acidity of the waste, (2) disposal of mining waste (tailings or residual sand and rock-solid waste), and (3) problems of indigenous people (regarding the issue of land 
where mining operations take place which is the centre of customary religion) (Al Araf, Anton Aliabbas, dkk., 2011).

Article 16 of Law No. 4/1982 states the following provisions: "Every plan which is thought to have a significant impact on the environment must be accompanied by an analysis of environmental impacts, the implementation of which is regulated by government regulations". As a follow-up to this law, the government issued Government Regulation Number 27 of 199 concerning Environmental Impact Analysis. The Indonesian Forum for the Environment, represented by Pius Ginting, gave a response that there had been human rights violations committed by Freeport and provided assistance to the Amungme tribe's filing, which said that the land of the Amungme people was forcibly taken and relocated to the lower part of the land in the Kamoro tribe (Al Araf, Anton Aliabbas, dkk., 2011).

Article 34 point 1 of the UUPLH states that every act of violating the law in the form of pollution and destruction of the Environment requires the person in charge of the business and / or activity to pay compensation and / or take specific actions. Environmental pollution is used in the provisions of article 1365 of the Civil Code which states that "every act that violates the law which brings harm to others obliges the person who due to his wrongdoing to issue the loss, to compensate for the loss". The Criminal Code is strengthened in Article 35, which states that the person in charge of a business and / or activity whose business and activity has a major and important impact on the Environment, which uses hazardous and toxic materials is responsible for the losses incurred, with the obligation to pay compensation directly and immediately at the time of environmental pollution and / or destruction.

The disputed land that is being fought over by the Amungme Adat Tribe is classified as a no-man's land because there is no concrete deed and a notary showing ownership of the land. So that according to the representatives of the Amungme Indigenous Tribe, the land is customary communal land, especially PT Freeport, only has the right to cultivate through concessions granted by the government. Land tenure by Freeport without a Free Prior Inform Consent (FPIC) process, that is, without involving the community in exercising the right to determine all types of activities carried out in communal land areas, which are disputed lands (Indra Nugraha, 2017).

The existence of customary rights as the property of orthodox communities is still recognized even though there are regulations on land rights according to the UUPA. Recognition given to ulayat rights is factually still ongoing, and its implementation must take into account the interests of the nation as a whole (A.P. Parlindungan, 1998). PT Freeport, which is not satisfied with continuously proposing the expansion of land concessions, is not under the concept of profit-sharing over land leases that should form the basis of this concession (Amiruddin \& Aderito Jesus de Soares, 2003).

The role of the state in regulating land ownership is also needed as stated in the LoGA in the "Opinion" section (d) states "... obliging the state to regulate land ownership and lead its use so that all land throughout the nation's sovereignty is used for the maximum great prosperity of the people ..." ". The main objective of this land ownership arrangement was not achieved at all in the Amungme-Freeport case. This is regulated by the 1945 Constitution Article 33 paragraph 3, which states, "The land, water and natural resources 
contained therein are controlled by the state and used as much as possible for the welfare of the people". The "prosperity of the people" contained in Article 33 paragraph 3 does not seem real at all today, especially the Amungme Tribe.

However, with the limited national economic conditions after the replacement of power, the government immediately took strategic steps by issuing the Foreign Capital Law (Law No.1 of 1967). The perception of development is that local people are only made labourers with wages that do not match the benefits that PTFI gets per year. Hundreds of thousands of tonnes of gold, silver and copper ores were produced and brought to America, which was taken from the State of Indonesia without any positive impact on the local community.

Moreover, this has not had a good impact on the economy of the Indonesian people to date due to the unbalanced and transparent system of profit-sharing between Freeport and the Indonesian government. The Freeport case contradicts the objectives of human resource management carried out by foreign investors who are deemed too open to doors for those who have gone too far. Foreign investment should only be used as an investor to finance the management of natural resources wisely, not to enter, organize and manage by opening companies and taking the wealth of this nation at will.

Contract of Work I in 1967 with a contract validity period of 30 years. Then in 1991, KK II was made with a mass valid for 50 years starting from Contract of Work I. Based on this Contract of Work II, PT Freeport's mining area increased by 6.5 million acres (or PT Freeport Indonesia started operating in Mimika district, Papua province in 1967 until now based on two contracts of work. Contract of Work I in 1967 with a contract validity period of 30 years. Then in 1991, a Contract of Work was made. II with a mass valid for 50 years, starting from the Contract of Work I (Adrianus Bintang Hanto Nugroho, 2014).

In addition to the work contract obtained from the government, PT Freeport has also obtained a permit from the Amungme tribe, which is a tribe whose land becomes Freeport's mining land by holding the January Agreement on January 8, 1974. January Agreement is an agreement containing a cooperation agreement between the Amungme and Freeport tribes. One of the contents of the January Agreement is that PT Freeport provides social facilities in the form of schools, health clinics, housing and shopping centres. Apart from these facilities, it was also agreed that Freeport should provide job opportunities for the Amungme tribe according to the company's development (Dewi Aryani, 2011).

In this case, the two Amungme and Kamoro tribes who own customary rights get the attention of PT Freeport Indonesia in terms of human resource development (HR). One of the simple programs of the PT Freeport Indonesia company through the LPMAK seventribe bureau is to give special attention to local communities where workers are allowed to attend education through an organization or institution called the Amungme and Kamoro Community Development Institute, (LPMAK). LPMAK is an institution that is legally incorporated and authorized to manage PT Freeport's corporate social responsibility partnership fund since 1996.

The Amungme Adat tribe as an integrated part of the customary community unit has the right to legal protection of the customary law community as confirmed in the 1945 
Constitution of the Republic of Indonesia, namely in Article 18B (2) which reads "the state recognizes and respects indigenous peoples and their rights. Traditional as long as it is still alive and following the development of society and the principles of the Unitary State of the Republic of Indonesia, which are regulated in law ".

The Amungme Customary Tribe through representatives of the Amungme Community Development Institute (from now on referred to as LPMA) and the Amungme Tribe Customary Institution (from now on referred to as LASA) filed a claim for ownership of disputed land on the basis that the disputed land is customary ulayat land, so the land should belong to the Amungme Indigenous Tribe. Moreover, the Amungme Indigenous Tribe, as part of the Papuan Community, has Special Autonomy rights granted by the State through Law Number 21 of 2001 concerning Special Autonomy for Papua.

The land is not only used for mere economic purposes, but the land is a legacy of their ancestors or as a symbol of the existence of the life of the local indigenous tribes. In human life, the land is inseparable from all the actions of humans themselves because the land is a place for humans to live their lives and the continuation of their lives. The relationship between humans and land can be interpreted as an essential relationship. This means that this relationship will be sustained continuously until one day, the man returns to the Creator with the place where his last journey was also through the land.

The problem of controlling disputed land which is claimed is the ulayat land of the Amungme Adat Tribe. Disputed land claimed by the Amungme Indigenous Tribe as the party with the right to manage the land. Because the use of land carried out by PT Freeport Indonesia is considered only to cause losses, using concrete evidence in the form of environmental destruction around the mining area (Addi M. Idham, 2017).

The disputed land that is being fought over by the Amungme Adat Tribe is classified as a no-man's land because there is no concrete deed and a notary showing ownership of the land. So that according to the representatives of the Amungme Indigenous Tribe, the land is customary communal land, especially PT Freeport, only has the right to use the concession given by the government. Land tenure by Freeport without a Free Prior Inform Consent (FPIC) process, that is, without involving the community in exercising the right to determine all types of activities carried out in communal land areas, which are disputed lands (Indra Nugraha, 2017).

In the implementation of mining activities carried out by PT Freeport, problems often occur. Problems and obstacles in providing legal protection for customary land in Papua, namely: In article 20 paragraph (1) of Law Number 21 of 2001 concerning Special Autonomy for Papua, it regulates the provision of suggestions, considerations and approval of the planned cooperation agreement made by the Government and Provincial Government with third parties in force in Papua Province specifically concerning the protection of the rights of indigenous Papuans. Paying attention to and channelling the aspirations and complaints of indigenous peoples, religious communities, women and society in general regarding the rights of indigenous Papuans, and facilitating follow-up resolution (I Nyoman Nurjaya, 2019).

The problem that occurs is that the absence of special autonomy in Papua which is centred at the provincial level, not decentralized to districts/cities, turns out also to 
make the spirit, aspirations and efforts to protect customary land in Papua inapplicable. Conflicts of interest between the Provincial Government and indigenous peoples in Papua have occurred repeatedly. So that efforts to lead to a prosperous society in Papua still have to be made even though various laws and regulations have been enacted (Suharyo, 2019).

The rate of deforestation of customary forests has subsided somewhat since the Constitutional Court decision Number 35 / PUU-X / 2012 dated May 16, 2013, stated that customary forests are no longer part of state forests. So if you count it, it has been more than 16 years from May 1967 to May 2013 that the customary law community lost their customary forest. Even now, obtaining the designation of customary forests is also not an easy thing, even though it has been facilitated by the Ministry of Forestry, because the primary key lies in the district government, whether or not they want to make a regional regulation or a Regent Decree regarding the existence of customary law communities as one of the conditions for establishing customary forests.

Of all the problems that have occurred between PT Freeport and the Amungme tribe, it is more detrimental to the Papuan indigenous people who have rights to their land and have legal protection. However, there is no law enforcement carried out by the government. It is not all the wrongdoing with PT Freeport. It's just that the government is not strict in enforcing the law. There needs to be a synchronization between the related laws and law enforcement and the imposition of strict sanctions for violators. If we look at the theory of justice proposed by Aristotle, which states that to measure justice, there are units that can be used, namely:

a A person does not violate the applicable law, so justice means according to punishment or "lawful", that is, the law must not be violated, and legal rules must be obeyed.

b A person may not take more than their rights so that justice means equal rights. In this case, equality is the correct proportion, midpoint, or equal distance between "too much" and "too little".

The conception of positivist legal theory adopted by PT Freeport Indonesia by relying on Contract of Work and Agreement to strengthen the essential position of the reasons for making use of property rights over disputed land is considered too 'idealistic' when the substance stated in the regulation is difficult to implement in a concrete manner proven by the high level of environmental damage that is raised. Meanwhile, from the perspective of the Amungme Adat Tribe, the problem of disputes over land rights is a simple thing that can be carried out, namely the return of ownership rights to land-based on the concept of natural law theory which is associated with the hereditary transfer of land which should be classified as customary ulayat land.

The conception of positivist legal theory and natural law theory adopted by each party should lead to the culmination of ideal justice, where the Amungme Indigenous Tribe and PT Freeport Indonesia carry out joint activities. Mining operational activities carried out by PT Freeport Indonesia should be more concrete implementation in the field concerning statutory provisions to minimize violations that occur and increase law enforcement oversight of the rights of indigenous Papuans. With a note that every effort 
to utilize natural resources must be carried out while respecting the rights of indigenous peoples, especially the Amungme Tribe.

The phenomenon of the emergence of conflict due to development in Indonesia began in 1969 when people protested and demonstrated to the government or specific projects in certain locations because they felt that the Amungme tribe had never been invited to dialogue about the mine exploration plan. Mount Grasberg contains abundant gold reserves and is the largest producer of gold mines in the world. Freeport's arrival threatens the indigenous Amungme tribe who live in the highlands around the mining project. The Amungme tribe is closely tied to their ancestral land.

For the Amungme tribe, the Grasberg mountain is considered sacred and highly respected. For the Amungme tribe, the land is depicted as a figure of a mother who feeds, nurtures, educates, and raises from infants, the elderly, to the end of life. Land with a habitat environment is seen as a place to live, garden, hunt, and the place where the spirits of their ancestors reside so that there are several locations such as caves, mountains, waterfalls, and graves that are considered sacred places.

Mining exploration activities by Freeport caused the Amungme tribe to be evicted from their customary land, especially after the signing of the January Agreement on January 8, 1974, which was an agreement between the Amungme and Freeport tribes where the Amungme tribe had to give up their land to become mining land. Freeport would, in return, give some social facilities. For this reason, PT Freeport Indonesia has determined its obligations to provide schools, provide scholarships and provide health services for indigenous peoples. As a result of the signing of this January Agreement, Amungme people are prohibited from entering their customary land around Tembagapura.

At that time the borderland was made of wire fences for the city of Tembagapura. It turns out that the facts in the field, according to PT Freeport Indonesia's Amungme customary leader violate the agreed agreement. The city of Tembagapura was expanded to 20 ha for employee housing purposes, and new land clearing for expansion in camps 50 and 59 and customary land was again seized.

The conflict continued with protests from the indigenous people, and the security apparatus responded by bombing the villages of the Amungme tribe, Sikal village (Baliem valley) and others in 1977. Incidental resistance continued, and the biggest rioting occurred in January 1996, killing dozens of people, both indigenous people. And the security apparatus. This riot got the attention of national and international (American) NGOs who asked the government to resolve the conflict immediately.

The response came from PT Freeport Indonesia by issuing a one per cent fund policy in July 1996. The funds were taken from the company's gross profit, which increased every year, according to PT Freeport Indonesia's production capacity. This fund by PT Freeport Indonesia is called the Freeport Fund for Irian Jaya Development (FFIJD). The use of this one per cent fund from the beginning caused controversy. The status of the fund creates problems and conflicts because the various parties involved interpret it according to their interests. According to PT Freeport Indonesia, the funds are used for the development of the welfare of the Papuan people in general and the Amungme people in particular whose land is affected by the PT Freeport Indonesia mining project. 
After more than 30 years of Freeport's presence and activities on the customary land belonging to the Amungme tribe, the reality is that the living conditions of most of the Amungme tribe have not changed at all from before Freeport's arrival. In fact, at this time the existence of the Amungme tribe is mired in a deplorable condition. Muhammad Mansur, a member of Commission X DPR RI, when visiting Timika revealed that Freeport's presence in Timika did not bring any improvement to the Amungme and Kamoro tribes. The Amungme and Kamoro communities remain poor. Their land which was confiscated by Freeport has brought tremendous benefits to mining owners and their cronies in Indonesia.

It is undeniable that Freeport has invested billions of US dollars worth of investment and established various other modern facilities and infrastructure in the Freeport concession area on the communal land of the Amungme tribe. However, all of this clearly cannot be compared to the amount of sacrifice that the Amungme people have experienced so far. Instead of making the community prosperous, the construction and construction of various facilities and infrastructure were only done for the sake of exploitation and development of the Freeport company, rather than considering their usefulness for the Amungme community.

The philosophical dilemma that occurs between the Amungme Indigenous Tribe and PT Freeport Indonesia, according to the author's opinion, can occur because of the basis for the use of legal theory used. The Amungme tribe insists on understanding the theory of natural law, where disputed land is land inherited from their ancestors. So automatically, the disputed land is land entitled to be fully controlled by the Papua Amungme Tribe. Meanwhile, from the perspective of PT Freeport Indonesia, it uses positivism legal theory, where the basis for the provisions of the Contract of Work and the Agreement Clause between the delegation of company representatives who have agreed with the 'representative' of the indigenous Sudanese tribe is a strong argument for claiming full control of the disputed land.

\section{Conclusion}

The problem of utilizing land rights between the Amungme Indigenous Tribe and PT Freeport Indonesia is caused by differences in the fundamental reasons used by each party in claiming disputed land ownership rights. The Amungme Adat tribe adheres to the teachings of the theory of the law of justice which is based on the inheritance of disputed land which is considered as ancestral land which automatically belongs to the Amungme Adat tribe. Meanwhile, from the perspective of PT Freeport Indonesia, they rely on the Contract of Work and Agreement as a strong basis for claiming ownership rights over disputed land based on the teachings of positivist legal theory. The conception of positivist legal theory and natural law theory adopted by each party should lead to the culmination of ideal justice, where the Amungme Indigenous Tribe and PT Freeport Indonesia carry out joint activities. Mining operational activities carried out by PT Freeport Indonesia should be more concrete implementation in the field concerning statutory provisions to minimize violations that occur and increase law enforcement oversight of the rights of indigenous Papuans. With a note that every effort to utilize 
natural resources must be carried out while respecting the rights of indigenous peoples, especially the Amungme Tribe..

The philosophical dilemma that occurs between the Amungme Indigenous Tribe and PT Freeport Indonesia, according to the author's opinion, can occur because of the basis for the use of legal theory used. The Amungme tribe insists on understanding the theory of natural law, where disputed land is land inherited from their ancestors. So automatically, the disputed land is land entitled to be fully controlled by the Papua Amungme Tribe. Meanwhile, from the perspective of PT Freeport Indonesia, it uses positivism legal theory, where the basis for the provisions of the Contract of Work and the Agreement Clause between the delegation of company representatives who have agreed with the 'representative' of the indigenous Sudanese tribe is a strong argument for claiming full control of the disputed land. This research is expected to be able to provide a new scientific treasure for the "ideal" settlement of land disputes between the Amungme Indigenous Tribe and PT Freeport Indonesia. Through an analysis of the conceptual approach, it is expected to provide answers to disputes with consolidation to find a middle way in the form of joint evidence from each party, then agree on the percentage of land that can be controlled by each party. 
UIRLawReview. 4(2): 23-39

\section{References}

2017. "Belum Bayar Ganti Rugi, Suku Amungme Kembali Gugat PT Freeport". The Global Review: Pemandu Informasi Perkembangan Dunia. https://theglobalreview.com/belum-bayar-ganti-rugi-suku-amungme-kembali-gugat-pt-freeport/

Addi M. Idham.. 2017. "Tokoh Suku Amungme Desak Freeport Pulihkan Tanah Adatnya". Tirto.id https://tirto.id/tokoh-suku-amungme-desak-freeport-pulihkan-tanahadatnya-cj7Y

Adrianus Bintang Hanto Nugroho. 2014. "Kekuatan Modal dan Perilaku Kekerasan Negara pada Masa Orde Baru dan Pasca Orde Baru: Studi Kasus Freeport". E-Journal Cakrawala Jurnal Penelitian Sosial Volume 3 Nomor 1 Tahun 2014. Salatiga: Universitas Kristen Satya Wacana.

Al Araf, Anton Aliabbas, dkk. 2011. Sekuritisasi Papua: Implikasi Pendekatan Keamanan terhadap Kondisi HAM di Papua. Jakarta: Imparsial.

Amirrudin dan Aderito Jesus de Soares. 2003. Perjuangan Amungme Antara Freeport dan Militer. Jakarta: ELSAM.

Anggun P. Situmorang. 2018. "Sejarah Freeport Indonesia Hingga Jadi Rebutan Negara Maju”. Merdeka.com issude 21 Desember 2018. https://www.merdeka.com/uang/sejarah-freeport-indonesia-hingga-jadi-rebutannegara-maju.html

P. Parlindungan.1998. Komentar Atas UUPA. Bandung: CV. Mandar Maju.

Dewi Aryani. 2011. "Kasus Freeport Hilangnya Nurani Pemerintah". AntaraNews.com issued 26 November 2011. https://www.antaranews.com/berita/286476/kasusfreeport-hilangnya-nurani-pemerintah

Dianto Bachriadi. 2017. Siapa Pemilik dan Pengguna Tanah? Akar-Akar Konflik Agraria dan Pelanggaran HAM pada Pertambangan Besar di Indonesia. Jakarta: Agrarian Resources Center.

Elza Syarief. 2012. Menuntaskan Sengketa Tanah Melalui Pengadilan Khusus Pertanahan. Jakarta: Kepustakaan Popular Gramedia.

Indra Nugraha. 2017. "Soal Penguasaan Lahan Freeport di Papua, Berikut Kata Komnas HAM". Mongabay: Situs Berita Lingkungan. https://www.mongabay.co.id/2017/02/27/soal-penguasaan-lahan-freeport-dipapua-berikut-kata-komnas-ham/

I Nyoman Nurjaya, "Pengelolaan Sumber Daya Alam Berbasis Masyarakat Hukum Adat perspektif Antropologi Hukum", (makalah disampaikan pada Seminar Nasional Pemberdayaan Hukum Tidak Tertulis Dalam Grand Design Pembangunan Hukum Nasional, BPHN Kementerian Hukum dan HAM, 27 Juni 2019).

Kartini Mulyadi dan Gunawan Widjaja. 2007. Seri Hukum Harta Kekayaan Hak-Hak Atas Tanah, Jakarta : Kencana. 
Laurensius Arliman S. 2015. Penegakan Hukum dan Kesadaran Masyarakat. Yogyakarta: Deepublish.

Levina Azaria Winantyo. 2018. “Penguasaan Hak Atas Tanah dengan Hak Pengelolaan yang dikuasai oleh PT Pertamina (Studi Kasus: Sengketa Komplek Militer antara TNI dengan PT Pertamina di Kebon Jeruk). Jurnal Jurist-Diction Volume 1 Nomor 2 November 2018. Surabaya: Fakultas Hukum Universitas Airlangga.

M. Syamsudin. 2008. "Beban Masyarakat Adat Menghadapi Hukum Negara". Jurnal Hukum Nomor 3 Volume 15 Julo 2008. Yogyakarta: Fakultas Hukum Universitas Islam Indonesia.

Mira Novana Ardani. 2017. "Kepemilikan Hak Atas Tanah Bagi Orang Asing di Indonesia". Jurnal Law Reform Volume 13 Nomor 2 Tahun 2017: Semarang: Program Studi Magister IImu Hukum Fakultas Hukum Universitas Diponegoro.

Supriyadi. 2010. Aspek Hukum Tanah Aset Daerah Menemukan keadilan, Kemanfaatan, dan Kepastian atas Eksistensi Tanah Aset Daerah. Jakarta : PT Prestasi Pustakaraya, hIm. 1

Nuruz Zaman. 2016. Politik Hukum Pengadaan Tanah. Bandung: Refika Aditama.

Nyoman Serikat Putra Jaya. 2016. "Hukum (Sanksi) Pidana Adat dalam Pembaharuan Hukum Pidana Nasional". E-Journal Masalah-Masalah Hukum Jilid 45 Nomor 2 April 2016. Semarang: Universitas Diponegoro.

O. Yudhi Setiawan, 2009, Instrumen Hukum Campuran Dalam Konsolidasi Tanah, Jakarta: Raja Grafindo Persada.

PT Freeport Indonesia. 2020. "Peningkatan Kapasitas Masyarakat, Memberdayakan Masyarakat, Menjaga Kebersamaan". https://ptfi.co.id/id/community-capacitybuilding

Peter Mahmud Marzuki. 2014. Penelitian Hukum. Jakarta: Kencana Prenanda Media Group.

Suharyo. 2019. "Perlindungan Hukum Pertanahan Adat di Papua dalam Negara Kesejahteraan".

A.Z. Nasution, 1995, Konsumen dan Hukum, Sinar Harapan, Jakarta.

Diamond, Larry dan Leonardo Molino. 2005. "Asseesing The Qualitt of Democarcy". The John Hopkins University Press, Biltomore.

Habernas, Jurgen. 1996. "Between Factsand Norm". Polity Press, Cambride.

Revitch, Diare dan Abiggil Therstrom (ed). 2005. Demokrasi Klasik dan Modern ditejemahkan oleh Hermoyo. Jakarta: Yayasan Obor Indonesia, Jakarta.

Robert, Andrew. 2010. "The Quallity of Democracy in Eastern Europe: Publik Prefernces and Policy Reform. "University Press, Cambride.

Santoyo Purwo, 2014 “Merancang Arah Baru Demokrasi Indonesia Pasca Reformasi”, KPG (Kepustakaan Populer Gramedia), Jakarta. 
UIRLawReview. 4(2): 23-39

Sugiono, 2012. ME \etode Penelitian Kuantitatif, Kualitatif dan R \& D. Alfabeta, Bandung

Shumpeter Joseph. 1950. Capitalism, Sosialism, and Democracy. Happer, Network.

Pito Andrianus Toni et all. 2006. Mengenal Teori-Teori Politik Dari Sistem Politik Samoai Korupsi. Nuansa, Bandung.

Yin, RK 2011. Qualititative Research: Form Star to Finish, N.Y: The Guiford Press, NY.

Ayu Pertiwi Diah, Sistem Pemilu Proporsional Daftar Di Indonesia: Melahirkan Korupsi Politik? Jurnal Trias Politica, Universitas Riau Kepulauan, Vol.2, No.1, PP.1-14.2018.

Doni Ramdani Muhammad dan Fahmi Arisandi. Pengaruh Penggunaan Sistem Pemilihan Umum Dewan Perwakilan Rakyat Proporsional Daftar Terbuka. Jurnal Reehtsvinding. Univeristas 17 Agustus 1945. Vol,3.PP.1-11, 2014.

Silalahi Agus, "Korelasi Pengaturan Sistem Pemilu Proporsional Terbuka Barbasis Suara Terbanyak Dengan Korupsi Politik di Indonesia". Jurnal Yustisia, Univeristas 11 Maret. Vol 4.No.1.PP.1-14, 2015.

https://www.republika.co.id/berita/nasional/politik/14/03/19/n2o11c-hasil-riset-inijumlah-

Arba, (2015). Indonesian Agrarian Law, Sinar Grafika, Jakarta.

Chomzah, Ali A., (2002). Land Law, Land Law Series I Awarding State Land Rights, Land Law II Certificate Series and Its Problems, Literature Achievement Publisher, Jakarta.

Gautama, S., (1990). Interpretation of the Basic Agrarian Law, Citra Aditya Bakti, Bandung.

Hatta, M. (1977). Elaboration of Article 33 in the Constitution of 1945, Mutiara, Jakarta.

Harsono, B., (2000),. Indonesian Agrarian Law, Djambat, Jakarta.

Indonesia, Constitution of 1945.

Indonesia, Law Number 5 of 1960 concerning Basic Regulations on Agrarian Principles.

Indonesia, Law Number 4 of 2009 concerning Mineral and Coal Mining.

Indonesia, Government Regulation 24 of 1997 concerning Land Registration.

Indonesia, Law Number 4 of 1996 concerning Mortgage Rights.

Indonesia, Constitutional Court Decision No. 001-021-022 / PUU-I / 2003 concerning Judicial Review Number 20 of 2002 on Electricity.

Manan, B., (1995). Growth and Development of the Constitution of a Country, Mandar Maju, Bandung.

Muljadi, K. and Widjaja, G., (2008), Rights to Land $i$ n the Series of Assets, Kencana, Jakarta.

Santoso, U., (2010), Registration and Transfers of Land, Kencana, Jakarta. 
UIRLawReview. 4(2): 23-39

Santoso, U., (2015), Land Acquisition of Land, Kencana, Jakarta.

Sitorus, O. and Dyawati, N., (1994), Land Rights and Condos A Legal Review, Dasamedia Utama, Jakarta.

Zarqoni, Muhammad M., (2015), Land Rights, Acquisitions, Origins and Derivatives, and Their Relationship with Legal Guarantees and Property Rights Protection, Achievement of Publisher Library, Jakarta. 